10.53116/pgaflr.2020.2.3

\title{
The Rules of Medical Experimentation on People in the Light of the Polish Law and Administrative Solutions
}

\author{
Justyna Kulikowska-Kulesza* - Dominik Kościuk** \\ * Justyna Kulikowska-Kulesza, PhD, Department of Administrative Law and Procedure, Faculty of \\ Law, University in Białystok, Poland, email: j.kulikowska@uwb.edu.pl, ORCID: https://orcid. \\ org/0000-0001-6934-9014 \\ ** Dominik Kościuk, PhD, Department of Administrative Law and Procedure, Faculty of Law, \\ University in Białystok, Poland, email: d.kosciuk@uwb.edu.pl, ORCID: https://orcid.org/0000- \\ 0002-2695-8212
}

\begin{abstract}
In the history of mankind there are known cases of conducting experiments with a goal against people. After all, there has been eugenic research, or research leading to the creation of biological weapons. Such experiments are usually hidden from the public and governed by the internal and classified regulations of particular states. That is why it is important for the domestic legal orders world-wide to establish not only research methods and ways of conducting experiments (from the point of view of medical art and effectiveness of research) but also - and perhaps even more importantly - legal principles and rules limiting the conduct of medical experiments, and to establish rules of conduct with the effect of saving and prolonging the life and health of the patient. This article will analyse the Polish legal regulations and Polish doctrine in the field as a case study, describing an example of the national measures implemented to provide control of the research and medical experiment procedures.
\end{abstract}

Keywords: medical experiments, administrative procedure, decision, opinion, administrative court

\section{Introduction}

It is evident that in practice, a medical experiment is associated with a potential benefit for a specific patient (because it consists in the application of a new method of treatment when the existing ones are unreliable or do not exist at all), while a research experiment is not necessarily the same, because its aim is to gain knowledge about the processes and phenomena taking place in the human body, and a person subjected to such an experiment is often healthy and - through the experiment - exposed to the danger of losing this health. The benefit of a research experiment is only indirect, because it allows to improve the healing process in the future.

In the history of mankind, however, there are known cases of conducting experiments with a goal against people. After all, there has been eugenic research, or research leading to the creation of biological weapons. Such experiments are usually hidden from the public and governed by the internal and classified regulations of particular states. 
That is why it is important for the domestic legal orders worldwide to establish not only research methods and ways of conducting experiments (from the point of view of medical art and effectiveness of research) but also - and perhaps even more importantly - legal principles and rules limiting the conduct of medical experiments and to establish rules of conduct with the effect of saving and prolonging the life and health of the patient.

This article will analyse the Polish legal regulations and the Polish doctrine in the field as a case study, describing an example of the national measures implemented to provide control of the research and medical experiment procedures.

\section{Literature overview}

Polish law does not contain a legal definition of a medical experiment, but only introduces a division into therapeutic and research experiments, setting out general premises for the admissibility of experiments and specifying the procedure for obtaining permission to conduct them.

Therefore, it is worth answering the question whether the current provisions of the Polish law concerning the conduct of medical experiments are consistent and unambiguous enough to ensure that it is the patient's life and health that is the overriding value, and the observance of his/her health is guaranteed by law. In order to answer this question, it will be necessary, firstly, to define the notion of "medical experiment", secondly, to assess the premises of admissibility of conducting the experiment (including subjective limitations), and thirdly, to identify "procedural" principles and guarantees (understood as standards of conduct) leading to consent to the experiment.

\section{The term "medical experiment"}

As indicated in the introduction, the provisions of Polish law, namely Article 21(1) of the Law of 5 December 1996 on the professions of doctors and dentists (Official Journal of Laws 2018, item 617 with amendments, hereinafter referred to as PDD), do not contain a direct definition of a medical experiment, but only indicate that a medical experiment carried out on people may be a therapeutic or research experiment.

Therefore, in order to propose such a definition, attention should be paid to the notions of therapeutic and research experiment functioning in administrative law, as well as to the notion of medical experiment in criminal law.

A therapeutic experiment, in accordance with Article 21(2) of the PDD, is the introduction by a doctor of new or only partially tried-and-tested diagnostic, therapeutic or prophylactic methods with the aim of directly benefiting the health of the person treated. It may be carried out if the medical methods used so far are not effective or if their effectiveness is insufficient.

On the other hand, the research experiment, in accordance with Article 21 (2 and 3) of the PDD, is primarily aimed at broadening medical knowledge, but can be carried out 
on both sick and healthy individuals if participation is not associated with risk or if the risk is small and not disproportionate to the possible positive results of such an experiment.

In the criminal law there is a concept of the so-called innovative risk, which is stipulated in Article 27 of the Penal Code, which specifies that a person does not commit a crime, if he or she acts, among other things, in order to conduct a medical experiment, if the expected benefit is of significant cognitive and medical importance and the expectation of its achievement, the advisability and manner of conducting the experiment are justified in the light of the current state of knowledge. Requirements of a medical experiment, in accordance with the regulations of criminal law, are the consent of the participant on whom it is conducted and proper information about the expected benefits, the impeding negative effects and the likelihood of their occurrence, as well as the possibility to withdraw from participation in the experiment at any stage.

At the same time, it is claimed in the literature that the therapeutic experiment is mainly aimed at achieving a goal, which - as P. Daniluk writes - must be not any, but a direct benefit of the treated person, related to the improvement of his health. (Daniluk, 2005, p. 37)

B. Iwańska specifies that the connection with the so-called "direct benefit for health" is that the therapeutic experiment can be carried out only in circumstances when the medical methods used so far are not effective, or if the effectiveness of these methods is not sufficient. (Iwańska, 2000, p. 73)

In a lexicon article, Filar et alii also write about the healing purpose of this kind of experiment. In their opinion, the key is therapeutics, which involves the use of new or previously unused methods, techniques and procedures that have not been tested or have been examined "poorly", and as such, are not routinely applied. Above all, however, according to Filar et alii, the essential feature of a therapeutic experiment is that the experimenter intends "to treat, not to investigate". (Filar et al., 2004)

The therapeutic experiment also involves the introduction of new prophylactic methods. This is pointed out by O. Nawrot and A. Wnukiewicz-Kozłowska, who write that the legislator predicted that this experiment is not only the introduction of new or only partially tested prophylactic methods by a doctor. (Nawrot \& Wnukiewicz-Kozłowska, 2015) These authors present an opinion that since prophylaxis is often carried out on people who are not currently ill (because the prophylaxis is supposed to serve prevention, not treatment), the experiment can also be carried out on healthy people. The authors claim that the potential health benefit could then consist in examining such a person (before administering e.g. a new vaccine) and possibly detecting the disease, which could then be treated.

Slightly different features characterise the research experiment. First of all, it is aimed at "improving", "gaining" medical knowledge. There is no key "direct benefit to health" as in the case of a medical experiment. The doctrine indicates that although the research experiment can be conducted with the participation not only of healthy people, but also of patients, in relation to whom the cognitive goal is to be achieved; the activities undertaken during this experiment are not, by definition, directly aimed at improving the health of the participant, but at the same time do not exclude such a therapeutic benefit. (Iwańska, 2000, p. 71) 
The literature also expresses ethical doubts related to this type of medical experiment. K. Sakowski points out that the basic aim of "cognition" is to expand empirical knowledge, to gain knowledge about certain processes and phenomena taking place in the human body. It is difficult to talk here about benefits for a particular patient. If any, it "consists in a possible progress in medicine, enriching the skills of doctors, and thus improving the healing process. The person subjected to the experience has no personal benefit for his or her health; on the contrary, his or her most precious goods are put at risk". The same author argues that the cognitive goal involves exposing the research subject to risk, and even sacrificing the interest of the participant in the research process for the benefit of higher goods, such as science, humanity, civilisation. (Sakowski, 2014)

To sum up the above, the main elements of therapeutic and research experiments appear to be the following: introduction by the doctor of new or only partially tested diagnostic, therapeutic or prophylactic methods; medical methods used so far are not effective or their effectiveness is not sufficient; broadening of medical knowledge; conducting on both sick and healthy persons; consent of the participant on whom the experiment is conducted and proper information about expected benefits and possible negative effects; direct health benefit; introduction of new prophylactic methods; broadening of empirical knowledge; gaining knowledge about certain processes and phenomena occurring in the human body; development of medicine without reference to the benefit of a specific patient.

It therefore seems justified to assume that a medical experiment is an empirical action carried out on a person who is duly informed of the expected benefits and risks of adverse effects, and consisting in expanding knowledge of the processes and phenomena taking place in the human body, followed by the possible implementation of new diagnostic, therapeutic or prophylactic methods, aimed at the direct or indirect benefit of the health of the researched subject or other people.

\section{Conditions for the admissibility of a medical experiment}

The doctrine concretises the prerequisites for the admissibility of a medical experiment, pointing to a number of limitations in their conduct. For example, M. Kopeć argues that the conduct of a research experiment is allowed only when participation in it is not associated with any risk or when the risk is small and not disproportionate to the possible positive results of such an experiment. (Kopeć, 2016)

Assessing the admissibility of an experiment, the premise of a significant therapeutic or cognitive benefit is highlighted by K. Buchała and A. Zoll who point out that the assessment of the significance of this benefit should be based on the current state of knowledge, and thus on data objectively available to specialists in a given field, concerning recognised theoretical rights, research conducted so far and their results, including information concerning similar experiments and their results. (Buchała \& Zoll, 1998, p. 259)

M. Nesterowicz writes that the admissibility of a therapeutic experiment depends on the existence of two conditions. Firstly, the so-called incurable state, which is connected with the fact that commonly used therapeutic means are not sufficient to cure the patient. 
On the other hand, it is necessary to establish that the risk of the experiment is proportionate to the expected benefits. This means that the experiment should not be carried out when the intended benefits are disproportionate to the risk of deterioration of the patient's health, in particular when the development of the disease is not life-threatening. (Nesterowicz, 2013, pp. 240-241)

E. Zielińska allows conducting a medical experiment in connection with the "risk of novelty", adding that the expected result of the experiment is to have a significant cognitive value from the point of view of the current state of knowledge, and the way it is conducted is to be justified and cannot be carried out without the patient's consent. (Zielińska, 2014)

In addition, the provisions of the generally applicable law in Poland contain a number of restrictions on the free conduct of medical experiments.

First of all, in accordance with the regulation of Article 22 of the PDD, an experiment may be conducted if the expected therapeutic or cognitive benefit is significant and the expected achievement of this benefit as well as the purposefulness and manner of conducting the experiment are justified in the light of the current state of knowledge and consistent with the principles of medical ethics. This means that the performance of the therapeutic experiment is closely related to the patient's ill health and the research experiment is associated with significant scientific and cognitive importance.

The Penal Code also applies to medical experimentation. From the wording of Article 27 of this act, we derive that a person does not commit a crime when he/she acts in order to conduct a medical experiment, if the expected benefit is of significant cognitive and medical significance, and the expectation of its achievement, the purposefulness and manner of conducting the experiment are justified in the light of the current state of knowledge; furthermore, that the experiment is inadmissible without the consent of the participant on whom it is conducted, who is duly informed about the expected benefits and the possible negative effects and the probability of their occurrence, as well as about the possibility to withdraw from participation in the experiment at each stage.

"Expected benefit" means that this provision does not justify crimes which have inadvertently (without the intention to achieve the expected results of the experiment) led to benefits for the patient's health or medical development. This is confirmed by the case law of the Polish Supreme Court from the 1960s. The Court wrote: "For a risk to be considered as a basis for the exculpation of an accused person, it must be the result of a conscious decision on the undertakings which may be taken in various alternative forms" (the Supreme Court judgment of October 31, 1968, I KR 130/68, publ. OSNKW 1969, No 6, item 69).

The literature notes that Article 22 of the PDD does not explicitly mention the condition of "proportionality" between expected and adverse effects, but accepts that "the likelihood of the expected benefits exceeds (not necessarily seriously) the likelihood of injury resulting from the failure of the experiment”. (Kędziora, 2016, p. 298)

Undoubtedly, one of the most important conditions for the admissibility of conducting an experiment on a human being must be his/her explicit consent. This premise is contained in Article 25 of the PDD, which, in paragraph 1, requires the written consent of the person examined to participate in the experiment, whereas in the case of impossibility of giving written consent, the oral consent given in the presence of two witnesses is 
considered equivalent. Of course, even if a minor (a person between the ages of 13 and 18) is to take part in the experiment, the written consent of his legal representative is required. If the minor is able to give an informed opinion on his/her participation in the experiment, his/her written consent is also required. An additional condition for the admissibility of the experiment on a minor is that the expected benefits are of direct relevance to the minor's health and that the risk is low and not disproportionate to possible positive results. At the same time, a research experiment involving a person under 16 years of age is not admissible if it is possible to conduct such an experiment of comparable effectiveness with the participation of a person with full legal capacity [Article 25 (2) and (3) of the PDD].

Similar restrictions are contained in the PDD for a person who is incapacitated or does not have the ability to properly discern his or her participation in the experience. Paragraphs 4 and 5 of the above mentioned provision contain that in the case of a person fully incapacitated, the consent to participate in the therapeutic experiment is given by the person's legal representative, and if such person is able to express an opinion on his/her participation in the experiment, it is also necessary to obtain his/her written consent. On the other hand, in the case of a person who has full legal capacity but is not able to give an opinion on his/her participation in the experiment, his/her participation shall be authorised by the guardianship court having jurisdiction competent for the seat of the subject participating in the experiment.

The condition for consent shall be restricted in cases of urgency and imminent danger to life, as set out in Article 35(8) of the PDD. In such circumstances it is not necessary to obtain consent. At the same time, one should agree with the statement of D. Karkowska, who writes that "the patient has obviously the right not to be willing to be kept alive in a condition which he does not accept. On the other hand, the doctor has the right to save the patient's life, even if he does so against patient's will. At the same time, the doctor has the right and duty to use common sense to respect the patient's previously expressed will, primarily because of the asymmetry of information and the patient's incompetence in medical matters, which is generally an undeniable fact that strengthens the doctor's decision-making power. [...] However, when a patient is in a critical condition with no chance of avoiding death, the cessation of treatment is a duty, whether or not the patient has previously expressed a wish or not. It is required to respect the patient's right to a dignified and peaceful death". (Karkowska, 2009)

Subjective restrictions - resulting from the provisions of the law (Article 27 of the PDD) - have also been introduced for other persons who, by definition, are disabled or unable to defend their rights on their own. The Polish legislator has assumed that the participation of pregnant women in therapeutic experiment requires a particularly thorough assessment of the associated risks for the mother and the conceived child, and their participation in research experiments is only possible when the experience is not risky or the risk is low. On the other hand, it is excluded that conceived children, incapacitated persons, soldiers of the primary service and prisoners (deprived of liberty) take part in the research experiment.

An experiment shall be allowed only if the obligation to provide information referred to in Article 24 of the PDD is fulfilled. In accordance with that provision, the person to be subjected to the experiment shall be informed in advance of the aims, modalities and 
conditions of the experiment, the expected therapeutic or cognitive benefits, the risks and the possibility of withdrawing from the experiment at any stage. The obligation to provide information also applies to the experimenter during the execution of the experiment. If the immediate interruption of the experiment could cause a threat to life or health of the participant, the doctor is obliged to inform him/her about it.

It is worth emphasising, as R. Kubiak does, that such information should be simple and understandable even for a person with no life experience. He writes that "the experimenter should take into account the level of intelligence of the person being examined, the level of education, [...] his physical and mental state, and perceptual capabilities". (Kubiak, 2000, p. 50) At the same time, one should agree with the opinion of this author that the experimenter himself is not fully aware of the possible effects of the undertaken actions, and most often can only guess the effects of the conducted experiments. Therefore, it is not "possible for him to present to the participant of the experiment any information concerning the expected course of the experiment". (Kubiak, 2000, p. 433) At the same time, it is impossible not to notice that the legislator introduced a specific condition for the admissibility of a medical experiment of an administrative and legal nature. The possibility of implementing such an undertaking is subject to the consent of the relevant bioethics committee.

\section{Consent to the experiment as a result of the Polish administrative proceedings}

The content of Article 29 of the PDD indicates that a medical experiment may be carried out only after a positive opinion has been expressed on the project by an independent bioethics committee, adjudicating in a panel of persons of high moral authority and highly specialised qualifications. The committee's consent takes the form of a resolution, taking into account ethical criteria as well as the advisability and feasibility of the project.

Therefore, it should first of all be determined whether the committee's resolution (called an opinion) enabling the implementation of the experiment may be qualified as an administrative act, determining an individual case as referred to in the Polish Code of Administrative Procedure (hereinafter referred to as CAP), or whether it is only a consultative act, not of an administrative nature.

In order to do so, it is worth noting first of all that an "administrative matter" involves proceedings before public administrative authorities in individual cases falling within their jurisdiction, adjudicated by administrative decisions [Article 1(1)(1) of the CAP]. Thus, in a nutshell, if we are dealing with an "authority" (i.e. an entity whose competence lies in deciding on the rights or obligations of others), an "individual case" (concerning a specific natural or legal person, or even an organisational unit without legal personality), and an "administrative decision" (understood as a sovereign, unilateral decision on rights or obligations), these are the elements determining the existence of an administrative case.

It should be noted here that the jurisprudence of the Polish Supreme Administrative Court concludes that any case in which a public administration body is deciding on obligation of an entity concrete, is resolved by an administrative decision. This is "a situation in 
which three conditions are met. First, the public administration body applies a norm of substantive law based on generally applicable law. Secondly, that norm does not directly shape the substantive legal relationship in a way that does not require authoritative concretisation. Thirdly, finally, the standard does not indicate a form of administration other than a legal decision as being appropriate to be applied in this case". (See NSA, II GSK 1702/18, similarly Adamiak, 2005, pp. 17-18)

However, referring to the above mentioned medical experiment, it should be noted that it can be conducted only when an appointed entity (bioethics committee) gives a positive opinion on the application submitted by the doctor (researcher), based on sources of universally applicable law (e.g. DPP). Therefore, there should be no doubt that we are dealing with the above mentioned elements of an administrative case.

Such reasoning is confirmed by the Supreme Administrative Court's ruling (II OSK $1112 / 06$ ), often quoted in the literature, according to which the opinion issued by the bioethics commissions is an act constituting an independent resolution of an administrative case, containing consent or stating lack of consent to conduct a medical experiment. According to this court, the committee's position is an expression of knowledge and experience aimed at resolving the case, and thus the opinion is subject to appeal to the administrative court.

At the same time, it is impossible to disagree with the argument (from the same judgment) that "the statutory regulation of the issue of appointing bioethical committees, both at first and second instance, and entrusting bioethical committees with the task of deciding whether a medical experiment (an experiment project) proposed by a physician can be positively assessed, whether or not it meets the conditions for obtaining a positive opinion, and as a result, the decision on the admissibility of a medical experiment (since a positive opinion of the bioethics committee is a necessary condition for carrying out the experiment), which belongs to the forms of medical practice [Art. 2(3) od the PDD], places the said committee within the sphere of public administration, and its opinion is an act which is an independent resolution of an administrative matter initiated at the request of a doctor, considered according to the procedure defined by the legislator".

The scholarly supporters of this doctrine also intend to demonstrate that the commission's opinion is an expression of administrative authority, characteristic of public administration bodies. For example, P. Brzezicki claims that the commission "through its resolutions, opinions, decisions enter the scope of the constitutionally guaranteed freedom of scientific research, being able to limit or even exclude this freedom", and thus "it is undisputable that these entities [i.e. commissions - explanation added by the authors], within the scope of their authority, should be treated as part of the executive power as a structure performing functions in the field of public administration". (Brzezicki, 2012, pp. 9-10)

O. Nawrot and A. Wnukiewicz-Kozłowska also consider bioethics committees entities characterised by administrative power. They come to the conclusion that the committee is a control body of biotechnological development, understood as an institutionalised instrument of verification of medical experiments. In their opinion, these entities are equipped with the competence to legitimise experimental biomedical research involving humans. (Nawrot \& Wnukiewicz-Kozłowska, 2015) 
It is worth noting, in orderly fashion, that we have a completely exceptional situation in the case of the committee's judgments on clinical trials of a medicinal product (often also classified as medical experiments). In such experiments, the President of the Office for Registration of Medicinal Products, Medical Devices and Biocidal Products (formerly the Minister of Health) is the decision maker regarding the permission to start studies, and the opinion of the bioethics committee is only a part of the documentation attached to the application to start studies.

The Regional Administrative Court in Warsaw spoke in the case concerning this type of experiment, pointing out that "resolutions adopted by both the bioethics committees and the Bioethics Appeals Committee are opinions on the conduct of clinical trials" because "only the content of the opinion of the Bioethics Appeals Committee contained in the resolution after considering the appeal against the resolution of the bioethics committee is the basis for issuing an administrative decision of the Minister of Health [the Minister issued decisions in the previous legal status - explanation added by the authors], which constitutes a ruling on the merits of the case initiated by the motion of a person who has a legal interest in issuing this decision. In the case under consideration, such a decision was made by the Minister of Health" (Judgment of the Regional Administrative Court in Warsaw, VII SAB/Wa 15/14, publ. ONSA). Since clinical trials of a medicinal product are connected with a special procedure (conducted by the organ issuing the decision as indicated by the law), which has not been established in relation to other types of medical experiments, it is logical that the above statement of the court cannot be attributed to other resolutions of the committee, only for clinical trials of a medicinal product.

In our opinion, the opinion of the bioethics committee on the project of a medical experiment (not regulated by other provisions, such as those concerning research on medicinal products), expressed in the form of a resolution, constitutes the ruling administrative act (decision) referred to in CAP. Therefore, it is worthwhile to briefly draw attention to the basic procedural rules aimed at protecting procedural rights of a party to administrative proceedings, which should be applied in cases of issuing an opinion on a medical experiment. These principles are intended not only to ensure the formal correctness of the process leading to the issuance of an opinion, but also to protect the rights of the applicant and participants in the experiment.

First of all, the committee should have regard to the principle of legality, which states that administrative authorities only act on the basis of and within the scope of generally applicable law. It should therefore not, when preparing an opinion, justify a refusal (i.e. an unfavourable opinion) on the basis of reasons arising from sources of law of an internal nature (regulations, statutes, guidelines, etc.).

The principle of information as defined in Article 9 of the CAP should also be applied in the proceedings before the committee. That provision stipulates that public administration bodies are obliged to duly and exhaustively inform the parties of factual and legal circumstances that may affect the determination of their rights and obligations which are the subject of administrative proceedings, and that those bodies ensure that the parties and other persons participating in the proceedings are not harmed by ignorance of the law and, to that end, provide them with the necessary explanations and guidance. Therefore, it is worth noting that the committee should inform extensively - even before issuing an 
opinion - the entity submitting the experiment, not only about the applicable law, but also about other circumstances influencing the content of the decision. The bioethics committee should also pay attention to whether the experimenter will provide adequate information and whether he/she intends to inform the participants of the experiment about all aspects of the experiment that may affect their life or health.

Undoubtedly, the process before the bioethics committee should take into account the application of the principle set out in Article 11 of the CAP, i.e. active participation of the parties. The said provision stipulates that public administration bodies are obliged to ensure active participation of the parties at every stage of the proceedings and, before a decision is issued, to give them an opportunity to comment on the evidence, materials collected and demands made. This means that before the committee adopts a resolution, it should consider whether it bases it only on the documentation submitted by the applicant, or whether it has collected other evidence (documents, opinions, etc.) and, in such a case, it should give the entity intending to conduct an experiment the opportunity to inspect the entire documentation and then to comment on the evidence collected. This principle will not only protect the applicant, but will potentially lead to a fair explanation of the case, and thus may reveal possible irregularities and attempts to act contrary to medical ethics.

The correct procedure before the committee should also be characterised by compliance with the provisions on formal correctness of the application. It follows from Article $63 \S 2$ of the CAP that an application should include at least an indication of the person from whom it comes, his/her address and request, and should satisfy other requirements set out in special provisions. Such a "special" provision is $\$ 4(2)$ of the Regulation of the Minister of Health and Social Welfare of 11 May 1999 on detailed rules for appointing and financing as well as the procedures for the operation of bioethics committees (Official Journal of Laws $1999 \mathrm{nr}$ 47, item 480 as amended), from which we derive that the application should contain: designation of the person or other entity intending to conduct the medical experiment, and in the case of a multi-centre experiment, also the names of all the centres in the country where the experiment is to be conducted; the title of the project, its detailed description and justification as to the advisability and feasibility of the project; name, surname, address and professional and scientific qualifications of the person in charge of the medical experiment; information about the insurance conditions of persons intending to participate in the medical experiment; data about the expected medical and cognitive benefits and, possibly, other anticipated benefits for persons subjected to the medical experiment.

In addition to the above elements, the following should be attached to the application [as indicated in $\$ 4$ (3) of the Regulation on detailed rules for appointing and financing as well as the procedures for the operation of bioethics committees]: a draft of the medical experiment; information intended for persons subjected to the medical experiment containing detailed data on the aims and principles of conducting the medical experiment; expected therapeutic and other benefits for these persons, and the risk associated with participation in the experiment; a form of consent of the patient subjected to the medical experiment; a declaration of acceptance of insurance conditions; a declaration submitted by the person subjected to the medical experiment, in which he/she agrees to the processing 
of data related to his/her participation in the experiment by the person or another entity conducting the medical experiment.

Such a detailed scope of the application undoubtedly affects the protection of the interest of the participants in the experiment, and this protection is strengthened by the disposition of Article $64 \$ 2$ of the CAP, according to which, if the application does not meet other requirements set out in the provisions of law [including the PDD and the Regulation - underlining added by the authors], the applicant should be summoned to remove the deficiencies within a specified period, not shorter than seven days, with the information that failure to remove these deficiencies will leave the application without consideration. It would therefore be illegal to consider an application for an experiment, despite its incompleteness (e.g. omitting any of the above mentioned elements).

The protection of the interests of the participants in the experiment is strengthened by the application of the CAP provisions and exceptions from the Regulation concerning the formal correctness of taking and preparing a decision (i.e. a committee's resolution). According to Article 107 of the CAP, the decision should contain: designation of the public administration body; date of issue; designation of the party or parties; indication of the legal basis; ruling; factual and legal justification; instruction on how to appeal against it, on the right to renounce the appeal, and on the consequences of renouncing the appeal; signature with the name, surname and official position of the employee of the body authorised to issue the decision, and - if the decision was issued in the form of an electronic document - a qualified electronic signature.

In order for the opinion to be legally adopted, the committee "decides" by secret ballot, with the participation of more than half of the committee's members, including the chairman or deputy chairman and at least two members of the committee who are not doctors. Only votes for or against the opinion may be cast in a vote. It should also be noted that the resolution is signed by the members participating in its adoption.

At the same time, it is clear that some of the general principles of administrative procedure are restricted in cases before committees. This is because the principle of speed of proceedings adopted in administrative proceedings (which implies that matters should be dealt with immediately, and sometimes within a month or two months) is limited. However, it follows from $\$ 6$ (8) of the Regulation of the Minister of Health and Social Welfare of 11 May 1999 on detailed rules for appointing and financing as well as the procedures for the operation of bioethics committees (Official Journal of Laws $1999 \mathrm{nr} 47$, item 480 as amended), that the committee expresses its opinion no later than within three months of receiving complete documentation of the experiment. This limitation appears to be justified. The extended period of investigation may lead to a reliable clarification of the case and a thorough examination of all aspects of the planned experiment. Similarly, it should be argued that it is appropriate to extend (beyond the standard month specified in the CAP) the time limit for the Board of Appeal to two months [ $\$ 8$ (3) of the Regulation].

Similarly, the principle of resolving the doubts in favour of a party (applicant, experimenter) should be subject to such restriction. The specific nature of an experiment requires the protection of essential goods (health and life) as a priority superior to the "development of medicine" and the "achievements of civilization". It is therefore justified - in proceedings concerning the issue of an opinion - to apply the exception specified in Article 
7a (2) (1) of the CAP, that this principle does not apply if an important public interest requires it. After all, it is primarily public (and also individual) interest to protect the life and health of people.

\section{Conclusions}

The analysis of the PDD regulations, in conjunction with the CAP, Penal Code and the interpretation of these regulations in the existing literature on the subject, allow to conclude that a medical experiment can be defined as such an empirical action - carried out on a person duly informed about the expected benefits and threatening adverse effects - which consists in expanding the knowledge of processes and phenomena occurring in the human body, and then the possible implementation of new diagnostic, therapeutic or prophylactic methods, aimed at the direct or indirect benefit for the health of the research subject or other people.

What is more, it is reasonable to conclude that the current legal regulations in Poland regulate the process of permitting medical experiments in such detail that no consent is likely to be given for unethical experiments which contradict to the idea of protecting life and health of every human being.

Not only the existence of a whole range of subjective and objective restrictions on conducting experiments on people is clear, but it is also possible to demonstrate the existence of procedural restrictions resulting from the law and administrative proceedings.

\section{References}

Adamiak, Barbara (2005). Zagadnienie domniemania decyzji administracyjnej [The issue of presumption of an administrative decision]. In Jan Boć \& Piotr Lisowski (Eds.), Podmioty administracji i prawne formy ich działania. Studia i materiały z konferencji jubileuszowej Profesora Eugeniusza Ochendowskiego [Administrative entities and legal forms of operation. Studies and materials from Professor Eugeniusz Ochendowski's jubilee conference]. TNOiK, Toruń.

Brzezicki, Paweł (2012). Zasady wnoszenia opłat na rzecz komisji bioetycznych w wieloośrodkowych badaniach klinicznych produktów leczniczych [Rules on the payment of fees to bioethics committees in multi-centre clinical trials of medicinal products]. Kwartalnik Prawa Publicznego XII, 3/2012. UKSW - TNOiK, Warszawa - Toruń. 9-17.

Buchała, Kazimierz \& Zoll, Andrzej (1998). Kodeks Karny, cz. ogólna, Komentarz [Penal Code, general part, Commentary]. Wydawnictwo Pravnicze, Kraków.

Daniluk, Paweł (2005). Cel leczniczy w świetle poglądów doktryny prawa [Therapeutic purpose in light of the legal doctrine]. Prawo i Medycyna, 6(2), 46-58.

Filar, Marian, Krześ, Sławomir, Marszałkowska-Krześ, Elwira \& Zaborowski, Piotr (2004). Odpowiedzialność lekarzy i zakładów opieki zdrowotnej [The responsibility of doctors and health care institutions]. Lex Online. https://bit.ly/3diPizg

Iwańska, Barbara (2000). Warunki prawne dopuszczalności przeprowadzania eksperymentów medycznych [Legal conditions for the admissibility of medical experiments]. Państwo i Prawo, 70(2), 56-70. http://czytelniaonline. $\mathrm{pl} /$ magazine/16777547/2000/2/toc

Karkowska, Dorota (2009). Prawa pacjenta [Patient rights]. Oficyna, Lex On-line. https://bit.ly/2XVQ8vp 
Kędziora, Renata (2016). Odpowiedzialność karna lekarza w związku z wykonywaniem czynności medycznych [Criminal liability of the doctor in connection with the performance of medical acts]. Wolters Kluwer, Warszawa.

Kopeć, Marcin (Ed.) (2016). Ustawa o zawodach lekarza i lekarza dentysty. Komentarz [Act on the professions of physician and dentist. Commentary]. Wolters Kluwer, Warszawa.

Kubiak, Rafat (2000). Zgoda uczestnika eksperymentu, cz. 1 [The consent of the participant in the experiment, part 1]. Prawo i Medycyna, 2(8).

Nawrot, Oktawian \& Wnukiewicz-Kozłowska, Agata (Eds.) (2015). Temida w dobie rewolucji biotechnologicznej wybrane problem [Temida in times of biotechnological revolution - selected problems]. Wydawnictwo Uniwersytetu Gdańskiego, Gdańsk.

Nesterowicz, Mirosław (2013). Prawo medyczne [Medical law]. TNOiK, Toruń.

Zielińska, Eleonora (Eds.) (2014). Ustawa o zawodach lekarza i lekarza dentysty. Komentarz [Act on the professions of physician and dentist. Commentary]. LEX On-line. https://bit.ly/2BgalyP

\section{Legal references}

Judgment of the Polish Supreme Court of October 31, 1968, I KR 130/68, publ. OSNKW 1969, nr 6, item. 69. Judgement of the VAC in Warsaw, June 25, 2014, VII SAB/Wa 15/14 (orzeczenia.nsa.gov.pl).

Order of the SAC, April 18, 2007, Ref. No. II OSK 1112/06 (orzeczenia.nsa.gov.pl). 